\title{
PENGEMBANGAN BAHAN AJAR MODUL BERBASIS CONTEXTUAL TEACHING AND LEARNING (CTL) KELAS IV TEMA 3 SUBTEMA 1
}

\author{
Prihatin Sulistyowati, \\ Novita Martika Putri \\ Universitas Kanjuruhan Malang \\ E-mail: prihatinsulistyowati@unikama.ac.id
}

\begin{abstract}
Abstrak
Proses pembelajaran pada Kurikulum 13 memerlukan komponen pendukung berupa bahan ajar. Bahan ajar yang praktis dapat berupa modul. Tujuan penelitian ini adalah untuk mengembangkan produk berupa bahan ajar modul berbasis Contextual Teaching and Learning (CTL) pada kelas IV Tema 3 Subtema 1. Jenis penelitian ini adalah penelitian pengembangan berdasarkan Model 4D yang dimodifikasi oleh peneliti dari 4 langkah menjadi 3 langkah penelitian. Validasi oleh tim pakar, validasi oleh peer reviewer,Uji coba lapangan terbatas terhadap 10 siswa SDN Bandungrejosari 2 Kota Malang, lembar observasi pengamatan aktivitas guru dan siswa. Efektifitas modul dari hasil belajar siswa berupa soal tes. Aspek kelayakan isi, penyajian, kebahasaan dan penilaian kontekstual masing-masing sebesar 92,71\%, 91,5\%, 93,06\%, dan 92\% yang berarti "Sangat Layak". Validasi yang dilakukan oleh guru kelas IV SD dengan presentase 93,75\% yang berarti "Valid". Diharapkan penelitian selanjutnya dapat mengembangkan produk ini dengan melakukan uji coba kelompok besar dan produk dapat disebar luaskan.
\end{abstract}

Kata Kunci: Modul Tematik, Contextual Teaching and Learning (CTL)

\begin{abstract}
The learning process on Curriculum 13 requires supporting components in the form of teaching materials. Practical teaching materials can be modules. The purpose of this research is to develop the product in the form of teaching materials of module based on Contextual Teaching and Learning (CTL) in Grade IV of Theme 3 Subtema 1. This type of research is a research development based on 4D model modified by researchers from 4 steps into 3 research steps. Validation by expert team, validation by peer reviewer, Field trial limited to 10 students of SDN Bandungrejosari 2 Malang, observation observation sheet of teacher and student activity. Effectiveness module is taken from student learning result in the form of test question. The results of the assessment of the appropriateness of content, presentation, compliance and contextual valuation were $92.71 \%, 91.5 \%, 93.06 \%$, and $92 \%$, respectively, meaning "Very Eligible". The results of the assessment of the validation conducted by fourth grade elementary school teachers with a percentage of $93.75 \%$ which means "Valid". It is expected that further research can further develop this product by conducting large group trials and products can be disseminated.
\end{abstract}

Keyword: Thematic Module, Contextual Teaching and Learning (CTL)

\section{PENDAHULUAN}

Pelaksanaan pembelajaran tematik di sekolah dasar sudah berlangsung sejak tahun 2006. Awal pelaksanaan pembelajar-an tematik dilaksanakan di kelas I, II, dan III pada jenjang sekolah dasar pada kurikulum KTSP. Seiring berjalannya waktu, diringi dengan perkembangan zaman dan teknologi, pelaksanaan pembelajaran tematik di sekolah dasar juga dilaksanakan di kelas IV sampai VI pada tahun 2013.Hal ini dilaksanakan karena disesuaikan dengan teori perkembangan kognitif, bahwa siswa SD masih belum bisa berpikir secara parsial atau terpisah-pisah, tetapi mereka berpikir secara holistik dengan subjek yang konkret. Depdiknas (2002) menyatakan bahwa, "pembelajaran tematik pada dasarnya merupakan model dari kurikulum terpadu yang menggunakan tema untuk mengait-kan beberapa mata pelajaran sehingga dapat memberikan pengalaman bermakna kepada peserta didik".

Berdasarkan uraian diatas dapat disimpulkan bahwa pembelajaran tematik adalah pendekatan pembelajaran yang mengintegrasikan berbagai kompetensi dari berbagai mata pelajaran ke dalam tema dengan proses pembelajaran yang bermakna disesuaikan dengan per-kembangan siswa. Pembelajaran yang dilaksanakan berkaitan dengan pengalam-an dan lingkungan siswa. Pembelajaran ini menekankan pada keterlibatan siswa secara aktif, maka dari itu proses 
pembelajaran menerapkan konsep belajar sambil melakukan.

Pelaksanaan pembelajaran di sekolah memerlukan perangkat pem-belajaran agar dapat berlangsung sesuai dengan kompetensi yang diharapkan. Dalam Permendikbud No. 65 Tahun 2013, dijelaskan bahwa penyusunan silabus dan RPP disesuaikan pendekatan pembelajaran yang digunakan. Perangkat pembelajaran tematik yang penting selain silabus dan RPP adalah bahan ajar. Bahan ajar memiliki posisi penting dalam pembelajaran, yakni sebagai representasi dari penjelasan guru.Salah satu jenis bahan ajar yang dapat kita gunakan adalah bahan ajar cetak berupa modul. Modul disebut juga media untuk belajar mandiri karena di dalamnya telah dilengkapi petunjuk untuk belajar sendiri (Susilo, Siswandari, \& Bandi, 2016).

Namun kenyataannya masalah yang dihadapi beberapa SD hampir sama yaitu tidak ada bahan ajar berupa printed text lain selain buku dari pemerintah yang digunakan dalam kegiatan pembelajaran. Kegiatan pembelajaran hanya mengguna-kan teks dari pemerintah, di sisi yang lain siswa membutuhkan bahan ajar yang dapat digunakan dalam kegiatan belajar di sekolah atau di rumah. Selain itu persedian buku dari pemerintah juga terbatas sehingga tidak semua siswa mendapatkan buku untuk belajar. Bahan ajar yang dikeluarkan oleh pemerintah sudah baik namun tidak semua karakteristik di setiap sekolah sama, untuk itu perlu adanya pengembangan bahan ajar yang harus disesuaikan dengan karakteristik masing-masing sekolah dan siswanya (Fitriyah:2015). Hasil analisis buku yang dilakukan oleh peneliti ada materi yang terbalik konsepnya yaitu pada materi kolase dan mozaik. Permasalahan pembelajaran seperti ini, juga terjadi di SDN Bandungrejosari 2 Kota Malang.

Materi yang diajarkan pada pembelajaran tematik tema 3 Peduli Terhadap Makhluk Hidup kelas IV Subtema 1 Hewan dan Tumbuhan di Lingkungan Rumahku adalah materi yang dikaitkan dengan keanekaragaman hewan dan tumbuhan di sekitar dan mengkaji hubungan yang terjadi antar makhluk hidup. Hal ini bertujuan untuk membuat siswa lebih pandai, bijak dan cinta ter-hadap lingkungan. Berdasarkan hasil analisis buku siswa pada tema tersebut ditemukan bahwa materi pembelajarannya sudah disesuaikan dengan karakteristik siswa, namun masih perlu adanya penekanan pada materi pembelajaran dengan daerah lingkungan tempat tinggal siswa seperti keberagaman hewan atau tumbuhan yang ada di lingkungan rumah siswa.

Untuk menghadirkan materi sesuai kondisi lingkungan siswa. Salah satu bahan ajar yang dapat membantu adalah modul. Prastowo (2011) menyatakan bahwa modul merupakan bahan ajar yang disusun secara sistematis dengan bahasa yang mudah dipahami oleh siswa, sesuai usia dan tingkat pengetahuan mereka agar mereka dapat belajar secara mandiri dengan bimbingan minimal dari pendidik. Penggunaan modul dalam pembelajaran bertujuan agar siswa dapat belajar mandiri tanpa atau dengan minimal dari guru. Di dalam pembelajaran, guru hanya sebagai fasilitator.
Untuk menghadirkan dan mengemas modul yang sesuai dengan per-kembangan siswa ada baiknya jika modul yang disusun berdasarkan kegiatan atau peristiwa yang terjadi di sekeliling siswa yang disebut dengan pendekatan kontekstual. Pendekatan kontekstual (CTL) adalah konsep belajar yang membantu siswa membangun penge-tahuannya sendiri berdasarkan peristiwa yang dialaminya yang dapat di-implementasikan dalam kehidupan sehari-hari. Berdasarkan hasil penelitian Hosnan (2014) menyimpulkan siswa akan belajar dengan baik jika apa yang dipelajari terkait dengan apa yang telah diketahui dan dengan kegiatan atau peristiwa yang terjadi di sekelilingnya

Adapun tujuan yang ingin dicapai adalah menghasilkan Bahan Ajar Modul Tematik Berbasis Kontekstual untuk Kelas IV Tema 3 Subtema yang valid dan layak untuk digunakan sebagai penunjang bahan ajar siswa kelas IV Sekolah Dasar.

\section{METODE PENELITIAN}

Metode penelitian menggunakan metode pengembangan. Pengembangan Modul mengacu pada model 4D dengan modifikasi. Menurut Wahyuningsih, Raharjo, and Masithoh (2013) model pengembangan 4D terdiri atas 4 tahap utama yaitu: Define (Pendefinisian), Design (Perancangan), Develop (Pengembangan) dan Disseminate (Pen-yebaran), namun pda penelitian ini hanya sampai pada tahap ke III. Berikut tahap penelitian:

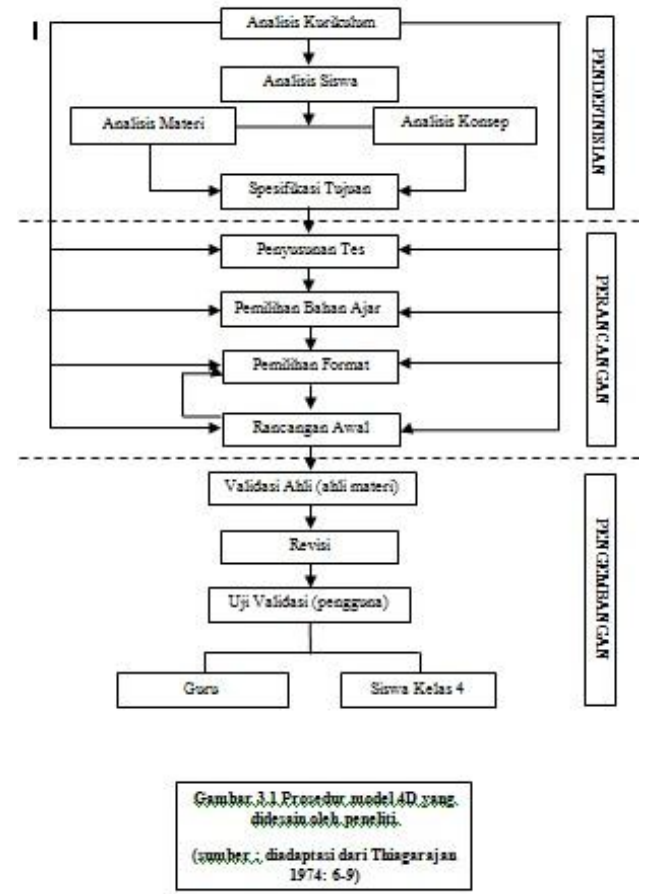

Gambar 1. Tahapan Penelitian

Subjek uji coba dibagi dalam beberapa tahap. Pada tahap validasi uji kelayakan dilakukan oleh dua orang ahli, pada tahap validasi oleh pengguna dilakukan oleh 2 orang guru kelas IV SDN Bandungrejosari 2 Kota Malang. Tahap ketiga pada uji coba lapangan terbatas dilakukan oleh 10 orang siswa kelas IV SDN 
Bandungrejosari 2 Kota Malang. Instrumen pada penelitian ini terdiri dari: lembar observasi pengamatan aktivitas guru dan siswa. Instrumen untuk mengukur efektifitas modul diambil dari hasil belajar siswa berupa soal tes.Teknik analisis data dalam penelitian ini menggunakan analisis data kuantitatif dan kualitatif.

\section{HASIL DAN PEMBAHASAN}

Hasil pengembangan bahan ajar modul pada penelitian ini, dijabarkan sebagai berikut:

\section{Tahap Pendefinisian}

\section{a. Analisis Kurikulum}

Pada langkah ini peneliti melakukan observasi dan wawancara terhadap guru kelas IV SDN Bandungrejosari 2 Kota Malang, dan wali murid kelas IV. Hal ini dilakukan untuk mengetahui permasalahan dasar yang dialami guru dan wali murid dalam proses pembelajaran yang menggunakan kurikulum 2013 khususnya pada Tema 3 peduli terhadap lingkungan hidup, subtema 1 hewan dan tumbuhan di lingkungan sekitar rumahku. Dari observasi yang dilakukan oleh peneliti dalam proses pembelajaran menggunakan K-13, tidak ada bahan ajar berupa printed text lain selain buku dari pemerintah.Di sisi yang lain siswa membutuhkan bahan ajar yang dapat digunakan dalam kegiatan belajar di sekolah atau di rumah. Selain itu persediaan buku dari pemerintah juga terbatas sehingga tidak semua siswa mendapatkan buku untuk belajar.

Hasil wawancara dengan seorang wali murid yang merasa terbebani dalam membantu belajar putranya pada pembelajaran tematik, karena tidak adanya bahan ajar lain bagi siswa di rumah. Sehingga siswa merasa kesulitan dalam mengikuti pembelajaran di sekolah serta tidak dapat mengerjakan tugas dan latihan yang terdapat pada buku. Di dalam buku teks dari pemerintah tidak terdapat banyak soal sebagai sarana berlatih menghadapi ulangan harian, ulangan tengah semester, dan ulangan semester.

\section{b. Analisis Siswa}

Dalam proses pembelajaran tema 3 subtema 1 siswa terlihat kurang aktif, jika guru bertanya hanya beberapa orang saja yang menjawab dan oleh siswa yang sama. Siswa mendapatkan pengetahuan hanya dari apa yang disampaikan oleh guru, siswa tidak mencari sumber lain misalnya, membeli buku yang berkaitan dengan materi atau mencari di internet. Dalam proses pembelajaran siswa masih pasif, karena materi yang ada di buku tidak semua ada di lingkungan sekitar siswa sehingga siswa hanya mendengarkan penjelasan dari guru dan mengerjakan soal-soal yang diberikan oleh guru.

Berdasarkan observasi siswa kelas IV SDN Bandungrejosari 2 Kota Malang dari aspek latar belakang kemampuan dapat disimpulkan bahwa kemampuan kognitif awal atau latar belakang kemampuan siswa kelas IV tersebut telah cukup memadai. Hal ini dapat dilihat pada nilai Ulangan tema 3 subtema 1 yang mereka peroleh dapat dilihat pada tabel berikut:

Tabel 1. Presentase nilai ulangan tema 3 subtema 1

\begin{tabular}{cc} 
Nilai & Presentase (\%) \\
\hline $90-100$ & $13,16 \%$ \\
$80-90$ & $36,84 \%$
\end{tabular}

\begin{tabular}{cc}
\hline Nilai & Presentase (\%) \\
\hline $70-80$ & $50,00 \%$ \\
$60-70$ & - \\
$50-60$ & - \\
\hline
\end{tabular}

\section{c. Analisis Tugas}

Analisa tugas berupa kompetensi yang akan dikembangkan dalam proses pembelajaran. Kegiatan ini ditujukan untuk mengidentifikasi keterampilan yang dimiliki oleh siswa yang akan di-kembangkan dalam pembelajaran dengan materi pada tema 3 subtema 1 . Analisis tugas dilakukan dengan cara meng-identifikasi materi utama yang perlu diajarkan, mengumpulkan data, dan me-milih materi yang relevan dan me-nyusunnya kembali secara sistematis. Analisis tugas dilakukan agar modul tema 3 subtema 1 berbasis contextual teaching and learning (CTL) benar-benar dapat membantu siswa belajar secara mandiri. Analisa tugas berupa kompetensi dan indikator yang dikembangkan dalam proses pembelajaran.

\section{d. Analisis Konsep}

Analisis konsep bertujuan untuk menentukan isi materi dalam modul tema 3 subtema 1 berbasis contextual teaching and learning (CTL) yang dikembangkan. Analisis konsep dibuat dalam peta konsep pembelajaran yang nantinya digunakan sebagai sarana pencapaian kompetensi tertentu dengan cara mengidentifikasi dan menyusun secara sistematis bagianbagian utama materi pembelajaran.

\section{e. Merumuskan Tujuan Pembelajaran}

Analisis tujuan pembelajaran di-lakukan untuk menentukan indikator pencapaian pembelajaran yang didasarkan atas analisis kurikulum dan analisis tugas. Dengan menuliskan tujuan pembelajaran, peneliti dapat mengetahui kajian apa saja yang akan ditampilkan dalam modul tema 3 subtema 1 berbasis contextual teaching and learning (CTL), menentukan kisi-kisi soal, dan akhirnya menentukan seberapa besar tujuan pembelajaran yang tercapai.

\section{Tahap Perancangan}

Pada tahap ini terdapat 4 kegiatan diantaranya: menyusun kriteria tes, pemilihan bahan ajar, pemilihan format, dan perancangan awal.

Pada tahap penyusunan instrumen didasarkan pada tujuan pembelajaran yang menjadi tolak ukur kemampuan siswa berupa kognitif, afektif, dan psikomotor selama dan setelah kegiatan pembelajaran. soal tes yang dibuat mengacu pada indikator pada tema 3 subtema 1, sedangkan pada tahap pemilihan bahan ajar yang dipilih oleh peneliti yaitu bahan ajar printed text berupa modul untuk memudahkan siswa menggunakan lang-sung dan disesuaikan dengan kemampuan kognitif dan lingkungan tempat tinggal siswa.

Adapun format yang digunakan dalam modul ini sesuai dengan karakteristik pembelajaran tema 3 peduli terhadap lingkungan subtemal hewan dan tumbuhan dilingkungan rumahku yang berbasis Contextual Teaching And Learning (CTL) dengan sintaks sebagai berikut: kontruktivisme, inkuiri, bertanya, masyarakat belajar, permodelan, refleksi, dan penilaian autentik. 
Pada tahap perancangan awal, dilakukan perancangan pembuatan bahan ajar modul, berikut deskripsi bahan ajar yang dikembangkan:

Modul terdiri atas tiga komponen yaitu awal, inti, dan penutup. Bagian awal modul memuat cover modul yang berjudul "Subtema 1 Hewan dan tumbuhan di lingkungan rumahku" lengkap dengan sub cover, kata pengantar, petunjuk pengguna-an modul, dan kompetensi inti. Bagian inti terdiri dari pemetaan kompetensi dasar subtema 1, peta konsep tiap pembelajaran, kegiatan: ayo mengamati! (kostruktivis-me), Pendalaman Materi, ayo lakukan! (inkuiri), ayo bertanya! (bertanya), ayo bekerjasama! (masyarakat belajar), ayo ikuti! (permodelan), ayo renungkan! (refleksi), sekarang aku bisa (penilaian autentik), dan ujian akhir subtema 1 . Bagian penutup pada modul berisi kunci jawaban, kamus mini, daftar pustaka, dan cover belakang modul .

Komponen komponen tersebut bertujuan untuk memudahkan siswa menggunakan modul dalam proses pembelajaran dan memahami materi. Komponenkomponen tersebut akan dibahas sebagai berikut:

1. Halaman sampul (Cover)

Pada halaman sampul meliputi beberapa hal sebagai berikut:

a. Judul

Judul yang ditentukan adalah :

Subtema 1:

HEWAN dan TUMBUHAN DI LINGKUNGAN SEKITAR RUMAHKU

MODUL BERBASIS CONTEXTUAL

TEACHING AND LEARNING (CTL)

b. Gambar Pendukung

Penyertaan gambar pendukung dalam cover depan adalah untuk menggambar secara singkat isi dari modul yang dikembangkan.

c. Sasaran Pengguna Modul

Dimaksudkan untuk memberitahu untuk kelas dan semester berapa modul tersebut.

d. Warna Background Modul

Pemilihan warna background dari cover modul yang dikembangkan adalh Hijau.

2. Sub Cover

Sub cover ini berisi tentang identitas modul. Pemberian tempat penulisan identitas modul adalah untuk mem-permudah dalam hal administrasi, sehingga jelas pemiliknya. Yang terdiri dari nama, asal sekolah dan kelas.

3. Kata Pengantar

Kata pengantar adalah bentuk pengungkapan pikiran penulis yang berisi antara lain sapaan kepada adikadik (dengan enanyakan kabar), meng-ingatkan tema sebelumnya yang sudah dipelajari, informasi tentang buku yang ditulis serta penjelasan singkat tentang ruang lingkup isi modul dan motivasi yang disampaikan penulis kepada pembaca.

4. Petunjuk Penggunaan Modul

Berisi petunjuk penggunaan modul yang harus dilakukan oleh siswa.

5. Kompetensi Inti
Kompetensi Inti adalah 4 kompetensi yang harus dicapai oleh siswa yaitu, religious, sikap, ilmu pengetahuan dan keterampilan.

6. Pemetaan Kompetensi Dasar Subtema 1

Berisi tentang kompetensi dasar apa saja yang harus siswa pelajari dalam tema 3 subtema 1 .

7. Peta Konsep

Peta konsep setiap pembelajaran berbeda karena setiap pembelajaran terdapat bebrapa mata pelajaran yang berbeda dengan pembelajaran se-belumnya. Peta konsep setiap pembelajaran ini berisi mata pelajaran yang ditematikan, Kompetensi dasar dan indikator.

8. Kegiatan “Ayo Mengamati!"

Sebelum memasuki pembelajaran, di awal anak diajak mengamati lingkungan sekitarnya sehingga anak dapat membentuk pengetahuannya sesuai dengan apa yang mereka amati.

9. Pendalaman Materi

Pada tahapan ini anak hanya memperdalam pengetahuan yang sudah mereka bentuk dengan konseo atau teori yang ada.

10. Kegiatan "Ayo Lakukan!“"

Pada tahap ini anak di minta melakukan atau mengikuti kegiatan sesuai dengan KD dan indikator. Tujuannya agar anak lebih memahami materi yang diajarkan. Karena dengan pengalaman anak melakukan kegiatan itu, pengetahuanya yang mereka dapatkan akan lebih bermakna dan lebih mudah mereka memahami konsep yang dipelajari.

11. Kegiatan "Ayo Bertanya!"

Kegiatan ni bertujuan mengembangkan sifat ingin tahu siswa dengan bertanya.

12. Kegiatan "Ayo Bekerjasama!"

Kegiatan ini bertujuan untuk mem-bantu siswa memahami bagaimana mereka saling mempengaruhi dan saling berkomunikasi baik dengan teman atau orangtua.

13. Kegiatan "Ayo Ikuti!"

Kegiatan ini bertujuan mengadirkan contoh atau kegiatan yang bisa diikuti oleh siswa sebagai contoh pem-belajaran atau panduan dalam memecahkan soal.

14. Kegiatan "Ayo Renungkan!”

Kegiatan ini bertujuan untuk mengingatkan kembali materi apa saja yang mereka pelajari di setiap pembelajaran.

15. Kegiatan "Sekarang Aku Bisa!"

Kegiatan ini bertujuan untuk me-ngetahui tingkat pemahaman siswa dalam pembelajaran tersebut.

16. Ujian akhir subtema 1

Kegiatan ini adalah evaluasi akhir dari proses pembelajaran 1 sampai pembelajaran 6 yang sudah di lalui oleh siswa.

17. Kunci Jawaban

Kunci jawaban berisi jawaban dari soal evaluasi setiap pembelajaran dan soal evaluasi akhir subtema.

18. Kamus Mini

Memuat kata-kata atau istilah penting, sulit, dan asing yang ada dalam modul yang disusun secara alfabetis. 
19. Daftar Pustaka

Daftar pustaka berisi pustaka atau daftar buku-buku referensi yang digunakan dalam menyusun modul ini.

\section{Tahap Pengembangan}

\section{a. Uji Kelayakan Modul oleh Tim Pakar}

Hasil uji kelayakan modul oleh tim pakar terhadap produk pada tabel 2

Tabel 2 Hasil Uji Kelayakan oleh Tim Pakar.

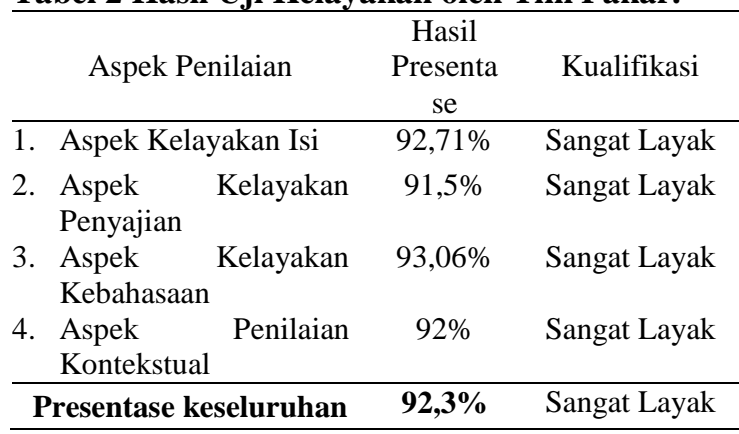

Selain memberikan penilaian terhadap modul tema 3 peduli terhadap lingkungan subtema 1 hewan dan tumbuh-an di lingkungan sekitarku berbasis Contextual Teaching and Learning (CTL), tim pakar juga memberikan saran dan masukan kepada peneliti agar modul layak digunakan sebagai sumber belajar oleh peserta didik.

Berdasarkan analisis nilai rata-rata bahan ajar modul baik dari aspek kelayakan isi, penyajian, kebahasaan dan penilaian kontekstual sudah dianggap sangat layak karena nilai rata-rata hasil uji validasi tiap komponen diatas 3 dan presentase kelayakan lebih dari $75 \%$ yang artinya bahan ajar modul yang dikembangkan menurut validator telah memenuhi indikator-indikator dari aspek kelayakan isi, penyajian, kebahasaan dan penilaian kontekstual.

b. Analisis Validasi Modul oleh Guru Kelas IV SD

Hasil validasi oleh guru kelas IV SD terhadap hasil pengembangan se-lengkapnya dapat dilihat pada tabel 3 .

Tabel 3. Hasil validasi oleh guru kelas IV SD

\begin{tabular}{lccc}
\hline \multicolumn{1}{c}{ No. } & $\begin{array}{c}\text { Aspek } \\
\text { Penilaian }\end{array}$ & $\begin{array}{c}\text { Hasil } \\
\text { Presentase }\end{array}$ & Kualifikasi \\
\hline 1. & Validasi 1 & $93,38 \%$ & Valid \\
2. & Validasi 2 & $94,12 \%$ & Valid \\
\hline \multicolumn{2}{l}{ Presentase keseluruhan } & $93,75 \%$ & Valid \\
\hline
\end{tabular}

Berdasarkan data hasil validasi dari segi materi, bahasa dan gambar, penyajian dan tampilan dari kedua validator mendapatkan presentase masing-masing $93,38 \%$ dan $94,12 \%$. Sesuai dengan kriteria validasi berdasarkan analisis rata-rata bahan ajar sudah dianggap valid karena nilai rata-rata hasil uji validasi dari kedua validator lebih dari $75 \%$.

Dengan demikian dapat disimpulkan bahwa bahan ajar yang dikembangkan telah memenuhi indikator dari segi materi, bahasa dan gambar, penyajian dan tampilan.selain memberikan penilaian terhadap bahan ajar modul, validator guru kelas juga memberikan saran yaitu ketepatan pemenggalan kata dan menambah katakata asing pada kamus mini.
Penambahan kata-kata asing pada kamus mini bertujuan untuk mem-permudah anak dalam mencari arti sebuah istilah yang tidak dimengerti. Berdasarkan hal tersebut penulis menambahkan beberapa kata asing.

\section{c. Uji Coba Lapangan Terbatas}

Uji coba lapangan terbatas dilakukan dari uji respon siswa dalam skala kecil yang dilakukan kepada 10 orang siswa kelas IV SDN Bandungrejosari 2 Kota Malang. Setelah siswa mempelajari modul tema 3 peduli terhadap lingkungan subtema 1 hewan dan tumbuhan di lingkungan sekitarku berbasis Contextual Teaching and Learning (CTL), kemudian siswa mengisi angket respon siswa yang diberikan oleh peneliti. Hasil penilaian yang diperoleh dari respon siswa yaitu dengan presentase 97,83\% dengan kategori "SANGAT SETUJU" Karena modul yang dikembangkan sudah memenuhi kriteria standart penilaian dengan melihat tiga aspek yaitu ketertarikan, materi, dan Bahasa, sehingga berdasarkan angket yang diberikan oleh peneliti kepada siswa setelah menggunakan modul tema 3 peduli terhadap lingkungan subtema 1 hewan dan tumbuhan di lingkungan sekitarku berbasis Contextual Teaching and Learning (CTL) dapat disimpulkan bahwa rata-rata siswa mengatakan modul menarik minat siswa untuk membacanya. Hal ini dikarenakan warna modul cerah, banyak gambar dan materi yang dimuat dalam modul ada di lingkungan sekitar siswa, dan bahasa yang digunakan mudah dipahami oleh siswa. Sesuai hasil penelitian Sudarno, Sunarno, and Sarwanto (2015) menunjukkan bahwa: Pengembangan modul IPA terpadu berbasis kontekstual menggunakan model Four-D kelayakan dikategorikan sangat baik berdasar kelayakan isi, penyajian, bahasa, kegrafikan, dan pendekatan pembelajaran;hasil uji $t$ berpasangan menunjukkan ada perbedaan yang signifikan rata-rata prestasi belajar siswa sebelum dan sesudah menggunakan modul IPA terpadu berbasis kontekstual, uji gain score dihasilkan $67 \%$ menunjukkan modul IPA terpadu berbasis kontekstual memiliki efektivitas sedang dengan pencapaian KKM 93,75\%.

\section{Hasil Lembar Observasi}

\section{Lembar Observasi Pengamatan Siswa}

Hasil data yang diperoleh dan hasil penilaian yang dilakukan oleh observer terhadap kegiatan siswa dapat diketahui presentase untuk setiap perpembelajaran yang ditunjukkan pada tabel 4 .

Tabel 4 Presentase Lembar Observer Kegiatan Siswa

\begin{tabular}{cc}
\hline Pembelajaran Ke- & Presentase \\
\hline 1 & $78,57 \%$ \\
2 & $81,43 \%$ \\
3 & $78,57 \%$ \\
4 & $81,71 \%$ \\
5 & $78,29 \%$ \\
6 & $76,00 \%$ \\
\hline Presentase Keseluruhan & $\mathbf{7 9 , 1 0 \%}$ \\
\hline Kualifikasi & BAIK \\
\hline
\end{tabular}

Berdasarkan tabel 4 diperoleh presentase total sebesar 79,10\% maka lembar observasi kegiatan siswa termasuk kategori "BAIK". Produk Pengembangan 
Bahan Ajar Modul yang sudah divalidasi tersebut dapat digunakan tanpa perlu adanya revisi.

\section{Lembar Observasi Pengamatan Guru}

Hasil data yang diperoleh dan hasil penilaian yang dilakukan oleh observer terhadap kegiatan guru dapat diketahui presentase untuk setiap perpembelajaran yang ditunjukkan pada tabel 5 .

Tabel 5 Presentase Lembar Observer Kegiatan Guru

\begin{tabular}{|c|c|c|c|c|c|c|c|}
\hline \multirow{2}{*}{ No. } & \multirow{2}{*}{$\begin{array}{c}\text { Aspek } \\
\text { yang } \\
\text { Dinilai }\end{array}$} & \multicolumn{6}{|c|}{ Pembelajaran Ke- } \\
\hline & & 1 & 2 & 3 & 4 & 5 & 6 \\
\hline 1 & 1 & 4 & 3 & 3 & 4 & 3 & 5 \\
\hline 2 & 2 & 3 & 4 & 4 & 4 & 4 & 5 \\
\hline 3 & 3 & 5 & 4 & 4 & 4 & 4 & 4 \\
\hline 4 & 4 & 4 & 5 & 4 & 3 & 4 & 5 \\
\hline 5 & 5 & 3 & 4 & 4 & 4 & 4 & 4 \\
\hline 6 & 6 & 5 & 5 & 4 & 4 & 4 & 4 \\
\hline 7 & 7 & 4 & 5 & 4 & 4 & 4 & 3 \\
\hline \multicolumn{2}{|c|}{$\begin{array}{c}\text { Jumlah Skor } \\
\text { (Ag) }\end{array}$} & 28 & 30 & 27 & 27 & 27 & 30 \\
\hline \multicolumn{2}{|c|}{$\begin{array}{l}\text { Jumlah Skor } \\
\text { Maksimal }(n)\end{array}$} & 35 & 35 & 35 & 35 & 35 & 35 \\
\hline \multicolumn{2}{|c|}{ Presentase \% } & 80 & 85.7 & 77.1 & 77.1 & 77.1 & 85.7 \\
\hline \multicolumn{2}{|c|}{ Kriteria } & $\mathbf{B}$ & SB & B & B & B & SB \\
\hline \multicolumn{2}{|c|}{$\begin{array}{c}\text { Presentase Rata- } \\
\text { Rata }\end{array}$} & \multicolumn{6}{|c|}{80.48} \\
\hline
\end{tabular}

Kriteria Klasikal

SANGAT BAIK

Berdasarkan tabel 5 diperoleh presentase total sebesar 80,48\% maka lembar observasi kegiatan guru termasuk kategori "SANGAT BAIK". Lembar observasi kegiatan guru yang sudah divalidasi tersebut dapat digunakan tanpa perlu adanya revisi.

\section{Tingkat Penguasaan Siswa}

Analisis tes kemampuan siswa dalam menguasai materi pembelajaran tema 3 subtema 1 dianalisis secara kuantitatif. Untuk analisis data secara kuantitatif menggunakan perbandingan pencapaian hasil belajar sesudah dan sebelum penggunaan modul dengan menggunakan rumus $\mathrm{N}$-gain.

Hasil analisis tes kemampuan siswa dalam menguasai materi pembelajaran tema 3 subtema 1 memperoleh rata-rata $\mathrm{N}$-gain sebesar 0,37 dengan intrepretasi "SEDANG".

\section{Penutup}

\section{Simpulan}

Kesimpulan pada penelitian ini adalah pengembangan Modul Tema 3 Subtema 1 Berbasis Contextual Teaching And Learning (CTL) ini menggunakan model 4-D (four D models) yang dimodifaksi oleh peneliti diambil tiga tahap saja yaitu tahap pendefinisian (define), Perancangan (design), dan pengembangan (develop). Tim pakar menyatakan modul ini layak digunakan, hal ini diketahui dari hasil penilaian dengan presentase 94,4\%, berkualifikasi "SangatLayak". Guru kelas IV SDN Bandungrejosari 2 Kota Malang juga menyatakan modul ini valid dengan mendapatkan presentase sebesar 93,75\%, dinyatakan "Valid" dan modul ini dapat diujicobakan dengan revisi. Hasil respon siswa pada uji coba lapangan terbatas mendapatkan presentase 97,83\% dengan Kualifikasi "Sangat Setuju".
Pelaksanaan pembelajaran menggunakan modul tema 3 subtema 1 berbasis Contextual Teaching And Learning (CTL) menunjukkan presentase keaktifan siswa mencapai $79,10 \%$ dan keaktifan guru menunjukkan presentase $80,48 \%$. Modul tema 3 subtema 1 berbasis Contextual Teaching And Learning (CTL) yang dikembang berdasarkan model 4D layak digunakan dengan indikator hasil belajar siswa baik dan siswa aktif.

\section{Saran}

Pemanfaatan bahan ajar modul berbasis Contextual Teaching and Learning (CTL) yaitu: Guru dan sekolah diharapkan lebih memanfaatkan sumber belajar di lingkungan sekolah/sekitar sebagai bahan ajar sehingga siswa mendapat pengetahuan langsung dan dapat mencapai tujuan pembelajaran sesuai KD dan Indikator serta diperlukan uji coba di sekolah lain sebelum dilakukan penyebaran atau diseminasi.

\section{DAFTAR PUSTAKA}

Depdiknas, P. K. B. (2002). Ringkasan Kegiatan Belajar Mengajar: Jakarta: Balitbang Depdiknas.

Hosnan, M. (2014). Pendekatan saintifik dan kontekstual dalam pembelajaran abad 21: Kunci sukses implementasi kurikulum 2013: Ghalia Indonesia.

Prastowo, A. (2011). Panduan kreatif membuat bahan ajar inovatif: Yogyakarta: DIVA press.

Sudarno, S., Sunarno, W., \& Sarwanto, S. (2015). Pengembangan Modul IPA Terpadu Berbasis Kontekstual Dengan Tema Pembuatan Tahu Kelas VII SMP Negeri 2 Jatiyoso. Inkuiri, 4(3), 104-111.

Susilo, A., Siswandari, S., \& Bandi, B. (2016). Pengembangan Modul Berbasis Pembelajaran Saintifik Untuk Peningkatan Kemampuan Mencipta Siswa Dalam Proses Pembelajaran Akuntansi Siswa Kelas XII SMA Ni Slogohimo 2014. Jurnal Pendidikan Ilmu Sosial, 26(1), 5056.

Wahyuningsih, T., Raharjo, T., \& Masithoh, D. F. (2013). Pembuatan Instrumen Tes Diagnostik Fisika SMA Kelas XI. Jurnal Pendidikan Fisika, 1(1), 111-117. 